\title{
PERENCANAAN PRODUKSI BIOGAS DARI PALM OIL MILL EFFLUENT UNTUK PEMBANGKIT LISTRIK: STUDI KASUS PABRIK KELAPA SAWIT SEI PAGAR Biogas Production Planning from Palm Oil Mill Effluent for Electric Generation: Case Study of Sei Pagar Palm Oil Mill
}

\author{
Novio Valentino, Dwi Lukman Hakim, Hana Nabila Anindita, dan Zulaicha Dwi Hastuti \\ Pusat Teknologi Sumberdaya Energi dan Industri Kimia \\ Badan Pengkajian dan Penerapan Teknologi (BPPT) \\ Gedung 625, Kawasan Puspiptek Serpong, Tangerang Selatan \\ Email : novio.valentino@bppt.go.id
}

\begin{abstract}
The annual rise of Crude Palm Oil (CPO) production lead to production raise of Palm Oil Mill Effluent (POME). POME has a high organic content which can pollute the environment if not treated properly. The high COD content of POME has potential for electric conversion by capturing the methane or biogas obtained from the digestion of POME. The potential production of POME from Palm Oil Mill (POM) in Sei Pagar has been observed in this study. Data such as COD, BOD, TSS, and volumetric rate of POME are collected from POM Sei Pagar and used as basic engineering design for biogas production process. In addition, the process planning also included in this study. Continues Stirred Tank Reactor (CSTR) is chosen for biogas digester since it is considered to be the most efficient way to produce biogas. Pre-treatment is needed before POME is introduced into CSTR. The biogas produced from this process needs to be purified before it enters gas engine to convert the biogas to become electricity. POME at flow rate capacity of $15 \mathrm{~m}^{3} /$ hour in POM Sei Pagar and the reactor feed duration of 16 hours, by the process chosen in this study can produce $119 \mathrm{~m}^{3} /$ hour of biogas that can be converted to $532 \mathrm{~kW}$ electricity.
\end{abstract}

Keywords: POME, biogas, COD, CSTR, basic design

\begin{abstract}
Abstrak
Produksi minyak mentah kelapa sawit yang mengalami peningkatan setiap tahunnya mengakibatkan meningkatnya pula produksi limbah cair kelapa sawit atau palm oil mill effluent (POME). POME memiliki kandungan organik yang tinggi sehingga tidak dapat dibuang secara langsung ke lingkungan. Di sisi lain, tingginya nilai COD dalam POME ini sebenarnya dapat memberikan potensi untuk konversi listrik dengan menangkap gas metana atau biogas yang dihasilkan melalui serangkaian tahapan proses peruraian POME. Dalam kajian ini dilakukan pendataan potensi POME dari Pabrik Kelapa Sawit (PKS) Sei Pagar serta perencanaan proses produksi biogas dari POME. Data yang didapat seperti nilai COD, BOD, TSS, dan debit digunakan sebagai basic engineering design produksi biogas dari POME. Dalam perencanaan proses dipilih reaktor CSTR untuk proses produksi biogas. Selain itu, dilakukan proses pre-treatment terlebih dahulu untuk menyesuaikan POME dengan kondisi optimum reaktor. Biogas yang dihasilkan akan dipurifikasi sebelum masuk ke gas engine dan diubah menjadi energi listrik. Dengan kapasitas limbah POME di PKS Sei Pagar yakni sebesar $15 \mathrm{~m}^{3} / \mathrm{jam}$ dan waktu pengumpanan 16 jam diharapkan mampu menghasilkan $119 \mathrm{~m}^{3} / \mathrm{jam}$ biogas yang kemudian dapat dikonversi menjadi energi listrik sebesar $532 \mathrm{~kW}$.
\end{abstract}

Kata kunci: POME, biogas, COD, CSTR, desain basis

\section{PENDAHULUAN}

Produksi minyak mentah kelapa sawit atau Crude Palm Oil (CPO) di Indonesia saat ini mengalami peningkatan setiap tahunnya. Berdasarkan data dari Gabungan Pengusaha Kelapa Sawit Indonesia (GAPKI), produksi CPO Indonesia mencapai 38,17 juta ton di tahun 2017, meningkat sebesar 18 persen dibandingkan produksi CPO di tahun 2016. Peningkatan produksi minyak kelapa sawit ini berimbas baik terhadap kegiatan ekspor Indonesia. Namun demikian, meningkatnya produksi minyak kelapa sawit ini juga secara otomatis meningkatkan produksi limbah atau produk samping dari PKS yang sebenarnya masih bernilai ekonomi dan energi tinggi bila dimanfaatkan dengan baik.

Sebuah PKS rata-rata menghasilkan 25-30\% produk utama berupa CPO dan inti sawit/kernel sebesar $5-7 \%$, sementara sisanya yakni sebesar $70-75 \%$ adalah residu hasil pengolahan berupa limbah (GAPKI, 2018). Salah satu limbah dari PKS adalah limbah cair Palm Oil Mill Effluent (POME). Limbah POME adalah salah satu produk samping dari PKS yang berasal dari kondensat dari proses 
sterilisasi, air dari proses klarifikasi, air hydrocyclone (claybath), dan air pencucian pabrik (Agamuthu, 1995). POME memiliki kandungan organik yang cukup tinggi, terdiri dari Chemical Oxygen Demand (COD) sebesar 53.630 mg/l, Biological Oxygen demand (BOD) sebesar 25.000 $\mathrm{mg} / \mathrm{l}$, dan Minyak dan Lemak sebesar 8.370 mg/l (Sri Rahayu dkk, 2015). Tingginya kandungan organik ini menyebabkan POME tidak dapat dibuang secara langsung ke lingkungan.

Di sisi lain, tingginya nilai COD dalam POME ini sebenarnya dapat memberikan potensi untuk konversi listrik dengan menangkap gas metana yang dihasilkan melalui serangkaian tahapan proses pemurnian. PKS dengan kapasitas produksi 30-45 ton TBS/jam berpotensi menghasilkan listrik dari limbah POME kurang lebih sebesar $1 \mathrm{MW}$. Provinsi Riau misalnya, yang memiliki 140 PKS memiliki potensi energi listrik dari POME sebesar $133 \mathrm{MW}$ yang dapat memenuhi sekitar $50 \%$ dari beban puncak energi listrik di wilayah Riau yakni sebesar 261,02 MW (PLN, 2015). Oleh karena itu, diharapkan pengembangan pembangkit listrik tenaga biogas dari limbah POME ini dapat membantu pemenuhan kebutuhan energi listrik di Indonesia.

Dalam kajian ini dilakukan pengumpulan data serta analisis potensi POME di PKS Sei Pagar sebagai bahan baku produksi biogas. Data-data yang dihasilkan akan digunakan dalam perencanaan proses produksi biogas, salah satunya menjadi basic engineering design untuk proses produksi biogas yang efektif dan efisien. Selain itu, berdasarkan hasil survei lokasi, dilakukan pula pembuatan Process Flow Diagram (PFD), serta tata letak (layout) untuk proses produksi biogas dari POME di PKS Sei Pagar.

\section{BAHAN DAN METODE PENELITIAN}

\subsection{Bahan}

Bahan yang digunakan dalam penelitian ini adalah POME yang diperoleh dari PKS Sei Pagar, Riau. Bahan lainnya adalah bahan kimia yang diperlukan untuk analisis karakteristik POME.

\subsection{Pendataan Potensi POME di PKS Sei Pagar}

Dalam tahap ini dilakukan pengumpulan data produksi TBS di PKS Sei Pagar sehingga dari data tersebut dapat diperkirakan jumlah POME yang dapat dihasilkan setiap harinya.

\subsection{Karakterisasi POME}

Karakterisasi POME terdiri dari pengukuran kadar COD, BOD, TSS (Total Suspended Solid) dan pengukuran $\mathrm{pH}$. Pengukuran COD, $\mathrm{pH}$, TSS mengacu pada standar prosedur SNI. Pengukuran BOD dilakukan dengan menggunakan standar prosedurAPHA (Novio,dkk. 2017).

\subsection{Pengukuran Debit POME}

Pengukuran dilakukan secara langsung di saluran fat pit. Pengukuran debit POME dilakukan di fat pit dan dilaksanakan pada saat proses produksi minyak sawit berlangsung. Pengukuran debit dilakukan dengan menggunakan bak penampung yang sudah diketahui volumenya dan stopwatch. Data debit yang telah diambil kemudian diolah untuk mengetahui debit rerata harian agar dapat dijadikan dasar untuk perencanaan proses produksi biogas (Mufida, et al. 2015).

\subsection{Analisis Teknis}

Setelah didapat data-data yang dibutuhkan kemudian dianalisis dan digunakan sebagai basis desain engineering produksi biogas dari POME. Selain itu dilakukan pula pembuatan PFD, serta tata letak (layout) untuk produksi POME berdasarkan data-data yang didapat dari survei lokasi PKS Sei Pagar.

\section{HASIL DAN PEMBAHASAN}

\subsection{Potensi POME untuk Produksi Biogas di PKS Sei Pagar}

Potensi POME untuk produksi biogas dapat dilihat dari data TBS yang digunakan di PKS Sei Pagar. Jumlah TBS yang digunakan di PKS Sei Pagar setiap bulannya yang berlangsung pada Januari 2013 sampai dengan Agustus 2018 dapat dilihat pada Gambar 1.

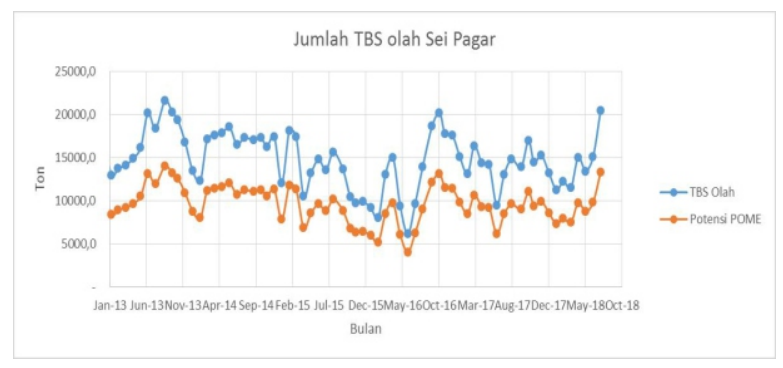

Gambar 1. Produksi TBS Olah dan Potensi POME di Sei Pagar

Berdasarkan Gambar 1, dapat diketahui bahwa produksi TBS olah di PKS Sei Pagar mengalami nilai yang fluktuatif. Pada setiap tahunnya, produksi TBS olah mengalami kenaikan produksi pada semester kedua kecuali pada tahun 2015. Produksi rata-rata TBS olah dari Januari 2013 sampai Agustus 2018 adalah 14.779 ton/bulan. Berdasarkan asumsi TBS olah akan menghasilkan POME sebesar $65 \%$ dari TBS olah maka jumlah potensi POME dapat diketahui. Potensi rata-rata produksi POME dari Januari 2013 sampai Agustus 2018 sebesar 9.606 ton/bulan atau 320 ton/hari.

\subsection{Analisis Karakteristik POME}

Pada tahap ini dilakukan analisis karakteristik dari POME. Pengujian karakteristik POME didasarkan untuk mengetahui kandungan yang terdapat dalam POME. Parameter-parameter analisis yang 
dilakukan terdiri dari COD, BOD, TSS, dan $\mathrm{pH}$, dimana karakteristik ini nantinya akan sangat berpengaruh terhadap proses produksi biogas. Hasil analisis karakteristik POME dapat dilihat pada Tabel 1.

Tabel 1.Karakteristik POME di PKS Sei Pagar

\begin{tabular}{llllll}
\hline $\begin{array}{l}\text { No } \\
\text { Sample }\end{array}$ & Tanggal & COD & $\mathrm{pH}$ & BOD & \multicolumn{1}{c}{ TSS } \\
\hline & Satuan & $\mathrm{mg} / \mathrm{l}$ & & $\mathrm{mg} / \mathrm{l}$ & $\mathrm{mg} / \mathrm{l}$ \\
\hline & & $\mathrm{SNI} 06-$ & SNI 06- & APHA & \multicolumn{1}{l}{ SNI 06- } \\
& Metode & $6989.2-$ & $6989.11-$ & $5210 \mathrm{~B}$ & $6989.03-$ \\
& & 2009 & 2004 & 2012 & 2004 \\
\hline 1 & $26 / 07 / 18$ & 44.208 & 3,88 & 10.999 & 3.322 \\
2 & $6 / 09 / 18$ & 36.221 & 4,5 & 24.320 & 5.205 \\
3 & $7 / 09 / 18$ & 37.934 & 4,33 & 13.749 & 21.490 \\
4 & $8 / 09 / 18$ & 34.792 & 4,01 & 14.299 & 6.675 \\
5 & $10 / 09 / 18$ & 48.036 & 4,06 & 12.099 & 4.230 \\
6 & $12 / 09 / 18$ & 41.772 & 4,19 & 9.899 & 13.487 \\
\hline
\end{tabular}

Analisis COD dilakukan untuk mengetahui banyaknya oksigen yang dibutuhkan untuk mengoksidasi kandungan organik seperti amonia dan nitrit. COD mencakup jumlah oksigen yang diperlukan untuk mengoksidasi senyawa organik menjadi $\mathrm{CO}_{2}$ dan $\mathrm{H}_{2} \mathrm{O}$. POME memiliki nilai COD yang tinggi. Hal tersebut menunjukkan bahwa kandungan organik dalam POME juga tinggi sehingga sangat baik untuk tempat berkembangnya organisme anaerobik, salah satunya yaitu bakteri metagenik yang akan menghasilkan gas metana atau biogas. Nilai COD berdasarkan Tabel 1 berada pada kisaran $40.000 \mathrm{mg} / \mathrm{l}$, sehingga nilai tersebut digunakan sebagai basis desain proses.

BOD didefinisikan sebagai banyaknya oksigen yang diperlukan oleh organisme pada saat pemecahan bahan organik, pada kondisi aerobik (Raliby, et.al., 2009). Pemecahan bahan organik diartikan bahwa bahan organik ini digunakan oleh organisme sebagai bahan makanan dan energinya diperoleh dari proses oksidasi. Penentuan BOD merupakan suatu prosedur yang menyangkut pengukuran banyaknya oksigen yang digunakan oleh organisme selama organisme tersebut menguraikan bahan organik yang ada dalam suatu substrat, pada kondisi yang harnpir sama dengan kondisi yang ada di alam. Parameter BOD juga penting untuk diperhatikan karena menunjukkan biodegradabilitas dari POME. Semakin tinggi nilai BOD/COD maka semakin tinggi pula biodegradabilitasnya sehingga semakin efektif pula untuk proses produksi biogas. BOD POME di PKS Sei pagar berkisar antara 10.000 - 15.000 $\mathrm{mg} / \mathrm{l}$.

TSS menggambarkan sejumlah padatan melayang yang ada dalam limbah dan tertahan oleh saringan dengan ukuran partikel maksimal 2 mikronn atau lebih besar dari ukuran koloid. Yang termasuk TSS adalah lumpur, tanah liat, logam oksida, sulfida, ganggang, bakteri dan jamur. TSS merupakan salah satu parameter yang perlu diperhatikan karena dapat mempengaruhi proses produksi biogas dalam digester. Semakin tinggi nilai TSS maka bahan organik membutuhkan lebih banyak oksigen untuk terdegradasi, dengan kata lain sulit untuk didegradasi.

Nilai pH POME berkisar 4 - 4,5. Menurut Saidu et.al., (2013), POME adalah koloid coklat krem dengan $\mathrm{pH} 4-5$, yang tergantung oleh kualitas bahan baku (TBS).Pada fermentasi anaerobik, pH merupakan salah satu faktor kritis yang mempengaruhi metanogen, dan karena itu secara langsung mempengaruhi produksi biogas dan metana (Chonga, et.al., 2017). Metanogen sangat rentan terhadap nilai $\mathrm{pH}$ sekitarnya. Oleh sebab itu, sebelum POME masuk ke digester maka POME tersebut harus di treatment terlebih dahulu sampai pH 6,5 sampai 7,8 (Anderson, et.al., 2003). Salah satu treatment untuk menjaga $\mathrm{pH}$ yaitu dengan recycle effluent dari digester.

\subsection{Pengukuran Debit POME}

Tujuan pengukuran debit yaitu untuk mengetahui debit limbah cair aktual yang keluar menuju ke kolam fat pit. Debit ini merupakan debit minimum yang keluar dari hasil proses pengolahan sawit. Hasil pengukuran debit limbah cair dapat dilihat pada tabel berikut.

Tabel 2. Pengukuran Limbah POME

\begin{tabular}{ccc}
\hline \multirow{2}{*}{ Pengulangan } & \multicolumn{2}{c}{ Debit $\left(\mathrm{m}^{3} / \mathrm{jam}\right)$} \\
\cline { 2 - 3 } & Hari ke-1 & Hari ke-2 \\
\hline 1 & 10,23 & 11,10 \\
2 & 10,50 & 10,35 \\
3 & 9,75 & 11,00 \\
4 & 10,27 & 10,37 \\
5 & 11,06 & 9,38 \\
6 & 10,35 & 10,13 \\
Rata-rata & 10,36 & 10,39 \\
\hline
\end{tabular}

Berdasarkan Tabel 2 di atas dapat diketahui bahwa debit POME rata-rata harian PKS Sei Pagar $10 \mathrm{~m}^{3} / \mathrm{jam}$ sehingga jumlah debit POME pada waktu tersebut sebesar $240 \mathrm{~m}^{3} /$ hari. Debit ini akan menentukan ukuran dan Hydraulic Retention Time (HRT) untuk proses yang efisien. HRT adalah lamanya substrat berada dalam reaktor digester.

\subsection{Basis Desain Proses}

Berdasarkan data yang telah didapat dari PKS Sei Pagar, dilakukan penentuan basis desain proses produksi biogas. Basis desain yang digunakan pada perancangan alat proses dapat dilihat pada Tabel 3.

\subsection{Process Flow Diagram serta Tata Letak Pilot Plant dan Peralatan Proses}

Pilot plant produksi biogas ini direncanakan berlokasi di PKS Sei Pagar. Kapasitas terpasang di pabrik tersebut adalah 30 ton TBS/jam dan menghasilkan limbah cair sekitar $10 \mathrm{~m}^{3} / \mathrm{jam}$. PFD yang digunakan untuk proses produksi biogas dapat dilihat pada Gambar 2 sedangkan tata letak pabrik dapat dilihat pada Gambar 3. Berdasarkan Gambar 2, dapat dilihat bahwa proses pengolahan 
POME menjadi biogas yang digunakan dalam kajian ini adalah dengan reaktor CSTR. CSTR adalah reaktor berbentuk tangki yang dilengkapi dengan sistem pengaduk. Substrat masuk ke dalam reaktor secara bertahap dan dilakukan pengadukan secara terus menerus. Penggunaan
CSTR memiliki banyak keuntungan diantaranya kontrol, monitoring, serta maintenance yang lebih mudah, produksi gas metana lebih tinggi, prosesnya lebih cepat dan tidak membutuhkan lahan yang luas (Ahmed, 2015).

Tabel 3. Basis Desain Proses

\begin{tabular}{|c|c|c|c|c|}
\hline No & Parameter Desain & Nilai & Satuan & Keterangan \\
\hline 1 & Laju alir POME & 240 & $\mathrm{~m}^{3} /$ hari & \\
\hline 2 & Laju alir POME & 15 & $\mathrm{~m}^{3} / \mathrm{jam}$ & \\
\hline 3 & Waktu pengumpanan & 16 & jam / hari & \\
\hline 4 & Rasio POME/ TBS & 0,65 & $\mathrm{~m}^{3} /$ ton TBS & \\
\hline 5 & COD & 40.000 & mg/l (ppm) & \\
\hline 6 & Efisiensi COD removal & $80-90$ & $\%$ & \\
\hline 7 & OLR & 3 & $\mathrm{~kg} \mathrm{COD} / \mathrm{m}^{3}$.hari & \\
\hline 8 & Digester active volume & 3.429 & $\mathrm{~m}^{3}$ & \\
\hline 9 & HRT & 14 & Hari & \\
\hline 10 & Rasio produksi metana/COD & 0,35 & $\mathrm{CH}_{4} \mathrm{Nm}^{3} / \mathrm{kg} \mathrm{COD}$ & \\
\hline 11 & Konsentrasi metana & 60 & $\%$ & \\
\hline 12 & Nilai Konten Energi Metana & 11,17 & $\mathrm{kWh} \_\mathrm{t} / \mathrm{m}^{3} \mathrm{CH}_{4}$ & \\
\hline 13 & Efisiensi Gas Engine & 40 & $\%$ & \\
\hline 14 & COD Load per hari & 9.600 & kg COD/hari & (Laju Alir) x (COD)/1000 \\
\hline 15 & Laju alir biogas $\mathrm{CH}_{4}$ & 119 & $\mathrm{Nm}^{3} \mathrm{CH}_{4} / \mathrm{jam}$ & \\
\hline 16 & Laju alir biogas $\mathrm{CH}_{4}$ & 2.856 & $\mathrm{Nm}^{3} \mathrm{CH}_{4} /$ hari & $\begin{array}{l}\text { (Efisiensi COD removal) x (Rasio produksi } \\
\text { metana/COD) x (COD load per hari) }\end{array}$ \\
\hline 17 & Laju alir biogas total & 4.760 & $\mathrm{Nm}^{3}$ biogas/hari & (Laju alir biogas $\mathrm{CH} 4$ ) /konsentrasi metana \\
\hline 18 & Laju alir biogas per jam & 198 & $\mathrm{Nm}^{3}$ biogas/jam & (Laju alir biogas total) / 24 \\
\hline 19 & Energi kalor per hari & 31.902 & $\mathrm{kWh} / \mathrm{d}$ & $\begin{array}{l}\text { (Nilai Konten energi metana) x (Laju alir } \\
\text { biogas } \mathrm{CH} 4 \text { ) }\end{array}$ \\
\hline 20 & Waktu operasi Gas Engine & 24 & jam/hari & \\
\hline 21 & Potensi Energi Listrik per hari & 12.761 & kWh/hari & (Energi kalor per hari) $x$ (efisiensi genset) \\
\hline 22 & Daya yang dibangkitkan per hari & 532 & $\mathrm{~kW}$ & (Potensi energi listrik per hari) / 24 \\
\hline
\end{tabular}

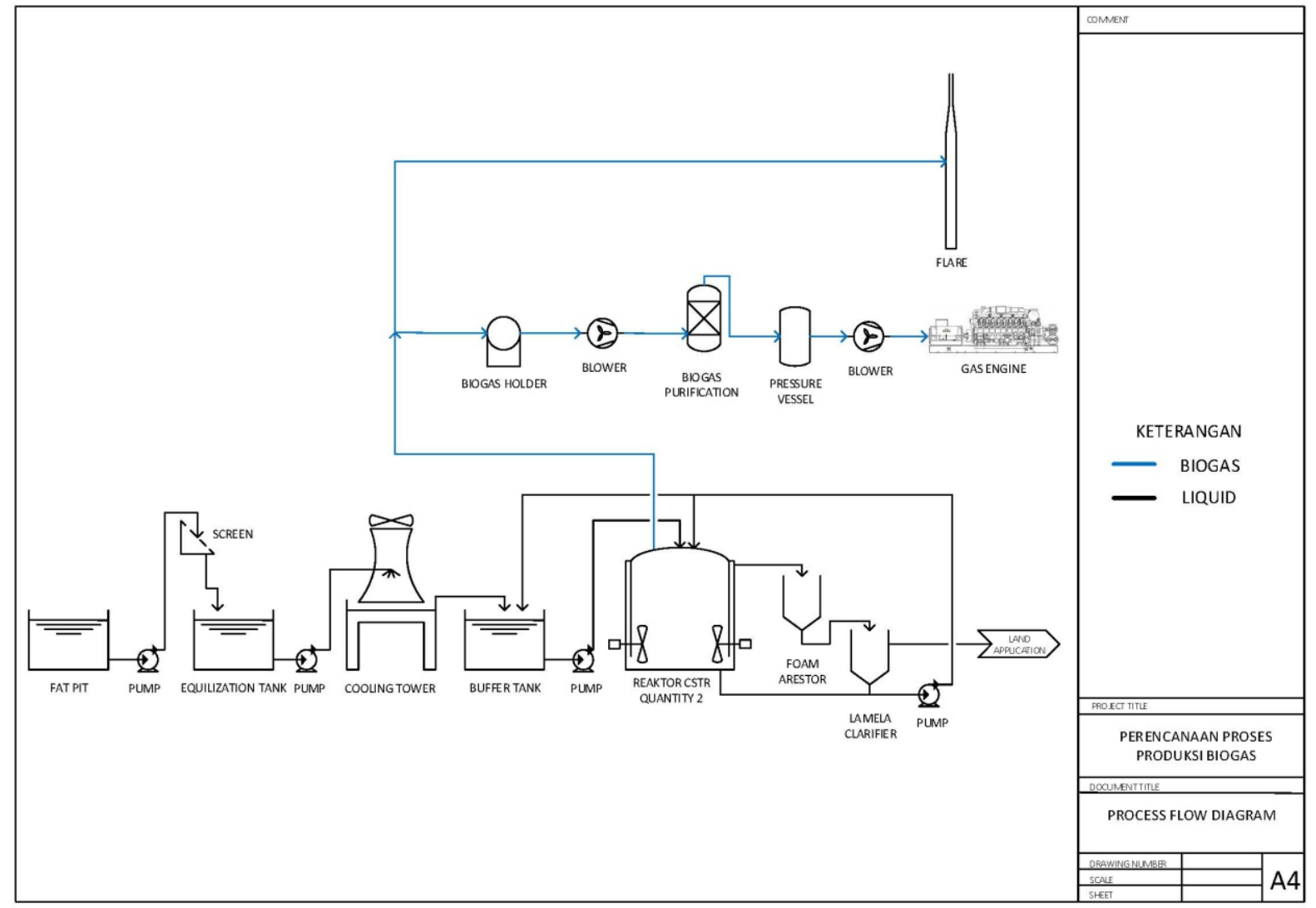

Gambar 2. Process Flow Diagram Produksi Biogas dari POME 




Gambar 3. Tata Letak Pabrik Biogas dari POME

Tabel 4. Perincian Luas Area Pabrik Biogas

\begin{tabular}{llrrr}
\hline \multirow{2}{*}{ No. } & Jenis Area & \multicolumn{2}{c}{ Ukuran $(\mathrm{m})$} & Luas \\
\cline { 3 - 4 } & & panjang & lebar & \multicolumn{1}{c}{$\left(\mathrm{m}^{2}\right)$} \\
\hline 1 & Vibrating Screen & 3,66 & 3,30 & 12,08 \\
2 & Equilization Tank & 8,00 & 8,00 & 64,00 \\
3 & Cooling Tower & 13,58 & 9,91 & 134,53 \\
4 & Buffer Tank & 8,00 & 6,00 & 48,00 \\
5 & Digester Tank 1 & 18,00 & 18,00 & 324,00 \\
6 & Digester Tank 2 & 18,00 & 18,00 & 324,00 \\
7 & Foam Aresster 1 & 3,00 & 2,50 & 7,50 \\
8 & Foam Aresster 2 & 3,00 & 2,50 & 7,50 \\
9 & Lamela Clarifier 1 & 7,20 & 7,00 & 50,40 \\
10 & Lamela Clarifier 2 & 7,20 & 7,00 & 50,40 \\
11 & Biogas Holder & 7,00 & 6,00 & 42,00 \\
12 & Biogas Engine & 12,50 & 5,00 & 62,50 \\
13 & Flare & 4,00 & 3,00 & 12,00 \\
14 & Control Room & 10,00 & 10,00 & 100,00 \\
& dan Lab. & 12,50 & 10,00 & 125,00 \\
15 & Gas & & & \\
& Management & & &
\end{tabular}

Selain itu, sebelum memasuki reaktor CSTR, bahan baku POME dikondisikan terlebih dahulu melalui proses pre-treatment dengan menggunakan screen untuk melakukan penyaringan tahap awal kemudian digunakan pula equalization tank, cooling tower, serta buffer tank untuk menyesuaikan suhu serta $\mathrm{pH}$ dari POME sehingga proses dalam reaktor CSTR menjadi lebih efisien. Biogas yang dihasilkan dari reaktor CSTR kemudian akan memasuki tahap purifikasi sebelum memasuki gas engine yang merubah biogas menjadi energi listrik. Berdasarkan Gambar 3, dapat dilihat bahwa akan digunakan dua buah reaktor CSTR. Alasan penggunaan dua buah reaktor ini adalah untuk mengantisipasi jika terjadi kerusakan pada salah satu reaktor maka proses produksi tetap bisa berjalan walaupun dengan kapasitas yang lebih sedikit. Selain itu, dalam reaktor CSTR untuk produksi biogas dibutuhkan proses pengadukan yang maksimal. Ukuran reaktor yang lebih kecil memungkinkan proses pengadukan yang lebih maksimal sehingga proses produksi biogas menjadi lebih efisien.

\section{KESIMPULAN}

Limbah cair kelapa sawit atau POME di Sei Pagar memiliki potensi yang baik untuk digunakan dalam proses produksi biogas. Dengan kapasitas limbah POME di Sei Pagar yakni sebesar $15 \mathrm{~m}^{3} / \mathrm{jam}$ dengan waktu pengumpanan 16 jam menghasilkan $119 \mathrm{~m}^{3} / \mathrm{jam}$ biogas yang kemudian dapat dikonversi menjadi energi listrik dengan kapasitas pembangkit sebesar $532 \mathrm{~kW}$. Dalam proses produksi biogas digunakan proses pre-treatment terlebih dahulu untuk mengkondisikan POME sebelum memasuki reaktor CSTR. Biogas yang 
dihasilkan kemudian dipurifikasi sebelum memasuki biogas engine sehingga pada akhirnya dihasilkan energi listrik yang dapat digunakan salah satunya untuk konsumsi listrik di PKS Sei Pagar.

\section{DAFTAR PUSTAKA}

Agamuthu, P., (1995). Palm Oil Mill Effluent and Utilization. $\boldsymbol{d}$ i dalam: C.A. Sastry, MA. Hashim and P. Agamuthu, (eds). Waste Treatment Plant. Narosa Publishing House, New Delhi. pp.338-360.

Ahmed Y., Yaakob Z., Akhtar P., Sopian K., (2015).Production of Biogas and Performance Evaluation of Existing Treatment, Renewable and Sustainable Energy Reviews 42. pp. 12601278.

Anderson K, Sallis P, Uyanik S., (2003). Anaerobic Treatment Processes. di dalam: Mara D, Horan N, editors. Handb. Water Wastewater Microbiol. London: Academic Press. 2003. p. 391-426.

APHA., (2012). Standard Methods for the Examination of Water and Wastewater. American Public Health Association Inc.Washington DC.

Bala, J.D., J. Lalung, and N. Ismail., (2014). Palm Oil Mill Effluent (POME) Treatment Microbial Communities in an Anaerobic Digester: A Review.International Journal of Scientific and Research Publications, 4(6): 1-24

GAPKI, (2018). Potensi Energi Listrik Limbah Sawit:Indonesia Jauh dari Krisis Energi, http://gapki.id/news/4066/potensienergi-listrik-limbah-sawit-indonesia-jauh-dari-krisis-energi, diakses 19 Februari 2018.

Hasanudin, U, R. Sugiharto, A. Haryanto, T. Setiadi, and K. Fujie., (2015). Palm Oil Mill Effluent Treatment and Utilization to Ensure the Sustainability of Palm Oil Industries. Water Science and Technolology, 72(7):1089-95.

Mufida, D. K., Sholichin, M., Cahyani, C., (2015). Perencanaan Instalasi Pengolahan Air Limbah (IPAL) Dengan Menggunakan Kombinasi Sistem Anaerobik-Aerobik Pada Pabrik Tahu “DUTA" Malang. Jurnal Pengairan.
Novio V., Zulaicha D.H, Agung W., (2017). Pengaruh Suhu Terhadap Proses Produksi Hidrogen dari Hasil Fermentasi Palm Oil Mill Effluent (POME), Enerlink Jurnal Energi dan Teknik Lingkungan. Vol.XIII No.2. hal. 43-46.

Poh, P.E. and M.F Chong., (2009). Development of Anaerobic Digestion Methods for PalmOil Mill Effluent (POME) Treatment. Bioresources Technology, 100: 1-9.

Raliby, O., Rusdjijati, R., Rosyidi, I., (2009). Pengolahan Limbah Cair Tahu Menjadi Biogas sebagai Bahan Bakar Alternatif pada Industri Pengolahan Tahu. Jurnal Litbang Provinsi Jawa Tengah - Vol.7 No.2.

Saidu, M., Yuzir, A., Salim, M.R., Salmiati, Azman, S., Abdullah, N., (2013). Influence of Palm Oil Mill Effluent as Inoculum on Anaerobic Digestion of Cattle Manure for Biogas Production. Bioresource Technology, Volume 141, pp. 174-176.

SNI, (2009). Air dan Air Limbah-Bagian 2: Cara Uji Kebutuhan Oksigen Kimiawi (Chemical Oxygen Demand, COD) dengan Refluks Tertutup Secara Spektrofotometer. SNI. 6989.2.2009.

SNI, (2004), Air dan air limbah - Bagian 11: Cara uji derajat keasaman $(\mathrm{pH})$ dengan menggunakan alat $\mathrm{pH}$ meter. SNI 06.6989.11.2004.

SNI, (2004).Air dan Air Limbah - Bagian 3: Cara uji padatan tersuspensi total ( Total Suspended Solid, TSS) secara gravimetri. SNI 06.6989.03.2004.

Sri Rahayu, Ade dkk., (2015). Konversi POME Menjadi Biogas Pengembangan Proyek di Indonesia. Winrock International.

Yee Yaw Choonga, Kian Weng Choua, Ismail Norlia., (2017). Strategies for improving biogas production of palm oil mill effluent (POME) anaerobic digestion: A critical review. Renewable and Sustainable Energy Review 